\title{
Initial development of corn subjected to increasing nitrogen doses
}

\author{
Dhiego César Oliveira Riva Neto ${ }^{1}$, Leonardo Rodrigues Barros ${ }^{2}$, Vinicius Silva Sousa ${ }^{3}$, Eliana \\ Paula Fernandes Brasil $^{3}$, Adriana Aparecida Ribon ${ }^{4}$, Alex Oliveira Smaniotto 5 \\ ${ }^{1}$ Instituto Federal de Educação, Ciência e Tecnologia de Mato Grosso, Campus Confresa, Confresa, Mato Grosso, Brasil. E-mail: \\ dhiego42@gmail.com \\ ${ }^{2}$ Universidade Estadual de Mato Grosso, Campus Nova Xavantina, Nova Xavantina, Mato Grosso, Brasil. E-mail: \\ barros.solos@gmail.com \\ ${ }^{3}$ Universidade Federal de Goiás, Campus Goiânia, Goiânia, Goiás, Brasil. E-mail: viniciusagro78@gmail.com, \\ elianafernandesufg@gmail.com \\ ${ }^{4}$ Universidade Estadual de Goiás, Campus Palmeiras de Goiás, Palmeiras de Goiás, Goiás. E-mail: aaribon@yahoo.com.br \\ ${ }^{5}$ Instituto Federal Goiano, Campus Rio Verde, Rio Verde, Goiás. E-mail: aosmaniotto@gmail.com
}

Received: 06/07/2020; Accepted: 23/02/2021.

\section{ABSTRACT}

Corn (Zea mays L.) is one of the most important cereals grown and consumed in the world not only for its economic value but also due to its importance in human and animal nutrition. This study aimed to assess the initial development of corn as a function of increasing nitrogen doses. The study was carried out in a greenhouse on the Sipal Farm, Confresa, MT, Brazil. The experiment was set up in a completely randomized design, consisting of five treatments $\left(0,100,200,300\right.$, and $400 \mathrm{mg} \mathrm{N} \mathrm{dm}^{-3}$ soil), with four replications, conducted from April to June 2020. Four seeds of the hybrid K 9606 VIP 3 were sown per 8-L polyethylene pot. The plants were thinned at 7 days after emergence (DAE), leaving only one plant per pot. Morphological components were assessed. A significant effect was found for almost all the analyzed parameters, except for stem diameter and root dry matter. The maximum plant height, shoot fresh matter, leaf area index, shoot dry matter, root fresh matter, and root volume was obtained by applying the maximum agronomic efficiency doses of 248.83, 271.90, 336.91, 279.66, 403.92, and $272.90 \mathrm{mg} \mathrm{N}$ $\mathrm{dm}^{-3}$ soil, respectively. Nitrogen doses influenced the initial development of the corn crop.

Keywords: Plant nutrition, nitrogen fertilization, Zea mays.

\section{Desenvolvimento inicial de milho submetido a doses crescentes de nitrogênio}

\section{RESUMO}

O milho (Zea mayz L.) é um dos mais importantes cereais cultivados e consumidos no mundo, não só pelo seu valor econômico, mas pela importância na alimentação humana e animal. Objetivou-se avaliar o desenvolvimento inicial do milho em função das doses crescentes de nitrogênio. O estudo foi realizado em casa de vegetação na chácara Sipal, município de Confresa-MT. O experimento foi estabelecido em delineamento inteiramente casualizado (DIC), constituído por 5 tratamentos 0, 100, 200, 300 e $400 \mathrm{mg} \mathrm{dm}^{-3} \mathrm{de} \mathrm{N}$ por $\mathrm{kg}$ de solo com 4 repetições, conduzido entre os meses de abril a junho de 2020. Na semeadura foi utilizado o híbrido K 9606 VIP 3 e vasos de polietileno de 8 litros cada vaso. Semeando 4 sementes e aos 7 dias após a emergência (DAE) realizado o desbaste das plantas, deixando-se apenas uma por vaso. Foram avaliados os componentes morfológicos. Constatou-se efeito significativo para todas as variáveis analisadas, exceto, para o diâmetro de colmo e massa seca de raiz da cultura do milho. A máxima altura de plantas, matéria fresca de parte aérea, índice de área foliar, matéria seca de parte aérea, matéria fresca de raiz e volume de raiz foi alcançada com a aplicação da dose de máxima eficiência agronômica de 248,83, 271,90, 336,91, 279,66, 403,92 e 272,90 mg dm³ de $\mathrm{N}$ por kg de solo, respectivamente. As doses de nitrogênio influenciaram no desenvolvimento inicial da cultura do milho.

Palavras-chave: Nutrição de plantas, Adubação nitrogenada, Zea mayz. 


\section{Introduction}

Considering the first and second growing seasons, the area planted with corn (Zea mays L.) in Brazil in the 2019/2020 agricultural year was estimated to reach 18.2 million hectares, with a production of 101.9 million tons (Conab, 2020). Corn is one of the most important cereals grown and consumed worldwide, providing products widely used for human and animal feed, and raw materials for industry (Alves et al., 2015). However, its cultivation is affected by management conditions, especially plant nutrition.

Nitrogen $(\mathrm{N})$ is one of the costliest inputs for corn production (Santos et al., 2018). It is the nutrient most absorbed by this crop and has a great influence on its yield (Caioni et al. 2016; Morais et al., 2018). Since Brazilian soils cannot meet corn $\mathrm{N}$ demand, supplementation with fertilizers becomes essential. However, $\mathrm{N}$ fertilization requires attention to time and application rates. While low $\mathrm{N}$ doses can limit corn yield, high doses lead to lodging, making harvesting difficult and decreasing yields (Teixeira Filho et al., 2010).

This macronutrient plays an important role in plant biochemical processes as a constituent of proteins, enzymes, coenzymes, nucleic acids, phytochromes, and chlorophyll (Farinelli and Lemos, 2012). It acts in photosynthesis and absorption of nutrients and water from the soil, directly influencing grain yield (Galvão and Miranda, 2011; Vieira et al., 2011). Its deficiency in corn may cause yield losses from 14 to $80 \%$ (Fancelli and Dourado Neto, 2000). Thus, studies on ideal doses and ways of making nutrients available to crops have become increasingly essential to maximize yields and reduce production costs (Rolim et al., 2018). In this context, it is known that $\mathrm{N}$ applied to the soil can be lost by leaching, runoff, denitrification, ammonia volatilization, and microbial immobilization (Alva et al., 2005).

The rational use of agricultural fertilizers, especially $\mathrm{N}$, has been gaining increasing importance due to its high economic and environmental costs, which is also associated with the increased demand for food. In this sense, this study hypothesized that a higher $\mathrm{N}$ availability can lead to changes in corn shoot and root system, having an impact on the initial development of corn plants, as $\mathrm{N}$ is a constituent of proteins, enzymes, coenzymes, nucleic acids, phytochromes, and chlorophyll. Therefore, we aimed to assess the initial development of corn as a function of increasing $\mathrm{N}$ doses.

\section{Material and Methods}

This study was carried out in a greenhouse on the Sipal farm, city of Confresa - MT (Brazil), at the geographic coordinates of $10^{\circ} 43^{\prime} 23.5^{\prime \prime} \mathrm{S}$ and $55^{\circ} 35^{\prime} 43^{\prime \prime}$ W, with an altitude of $239 \mathrm{~m}$, from April to June 2020. Four corn seeds of the hybrid K 9606 VIP 3 were sown per polyethylene pot, which had an 8-L capacity. The corn plants were thinned at 7 days after emergence (DAE), leaving only one plant per pot.

The soil used was classified as a dystrophic RedYellow Latosol (Oxisol) (Embrapa, 2018), with the following chemical and physical characteristics: $\mathrm{pH}$ $\left(\mathrm{CaCl}_{2}\right)=4.8 ; \mathrm{P}=12 \mathrm{mg} \mathrm{dm}{ }^{-3} ; \mathrm{K}=39 \mathrm{mg} \mathrm{dm}{ }^{-3} ; \mathrm{Ca}=$ $1.1 \mathrm{cmol}_{\mathrm{c}} \mathrm{dm}^{-3} ; \mathrm{Mg}=0.8 \mathrm{cmol}_{\mathrm{c}} \mathrm{dm}^{-3} ; \mathrm{Al}=0.2 \mathrm{cmol}_{\mathrm{c}}$ $\mathrm{dm}^{-3} ;$ CEC $=5.37 \mathrm{cmol}_{\mathrm{c}} \mathrm{dm}^{-3} ;$ base saturation $=$ $53.45 \%$; organic matter $=17.0 \mathrm{~g} \mathrm{dm}^{-3}$; sand $=670 \mathrm{~g}$ $\mathrm{kg}^{-1}$; silt $=70.0 \mathrm{~g} \mathrm{~kg}^{-1}$; and clay $=260.0 \mathrm{~g} \mathrm{~kg}^{-1}$. Base dressing consisted of $200 \mathrm{mg} \mathrm{P} \mathrm{dm}^{-3}$ soil and $100 \mathrm{mg} \mathrm{K}$ $\mathrm{dm}^{-3}$ soil.

The experiment was carried out in a fully randomized design, with five treatments consisting of increasing nitrogen $(\mathrm{N})$ doses $(0,100,200,300$, and 400 $\mathrm{mg} \mathrm{N} \mathrm{dm}{ }^{-3}$ soil), and four replications. Nitrogen fertilization was performed at 14 DAE using urea (45\% $\mathrm{N})$. When the plants were between the phenological stage V2 and V3 (40 DAE), the following morphological components were assessed: plant height, stem diameter, shoot fresh matter, root fresh matter, shoot dry matter, root dry matter, leaf area index, and root volume.

Plant height was measured in centimeters from the plant base to its apex, using a measuring tape. Stem diameter was measured in millimeters, using a caliper. Corn plants were collected and washed in water to remove excess soil, weighing shoots and roots separately for fresh matter determinations. Then, plant shoots and roots were dried in a forced-air circulation oven at $65{ }^{\circ} \mathrm{C}$, until reaching a constant weight for dry matter determinations. All leaves from the assessed plants were used for leaf area index determination, measuring the length and width of their blades, according to the method described by Francis et al. (1969) (Equation 1).

$L A=L \times W \times 0.75$

Wherein: LA is the leaf area, $\mathrm{L}$ is the leaf length, W is the largest leaf width, and 0.75 is the shape factor.

Root volume was determined using a 2,000-mL graduated cylinder filled with tap water to a volume of 1,600 $\mathrm{mL}$. The roots were dipped into the cylinder, and their volume was the difference between the initial and final volume in $\mathrm{cm}^{3}$.

Data were subjected to analysis of variance at $5 \%$ and/ or $1 \%$ probability by the F-test. If significant by the F-test, data on $\mathrm{N}$ doses were subjected to regression analysis, which was calculated for linear and quadratic equations, and accepted when significant up to $5 \%$ probability by the F-test. 


\section{Results and Discussion}

Table 1 displays a summary of the analysis of variance (F-test) for plant height, stem diameter, shoot fresh matter, root fresh matter, shoot dry matter, root dry matter, leaf area index, and root volume. A significant effect was observed for almost all parameters but stem diameter and root dry matter.

Plant height averages adjusted to the quadratic regression model as a function of the increase in $\mathrm{N}$ doses (Figure 1), with a coefficient of determination of $80.99 \%$ and a cutoff point of maximum efficiency at the dose of $248.83 \mathrm{mg} \mathrm{dm}^{-3}$.

Andrade et al. (2014) assessed corn performance under different $\mathrm{N}$ doses and found that they significantly influenced plant height, with results adjusted to the quadratic regression model. According to Veloso et al. (2006), such an increasing effect of $\mathrm{N}$ doses on corn heights can be explained by the fact that plants wellnourished in $\mathrm{N}$ exhibit better shoot and root development, as it increases cell division and expansion.

Conversely, stem diameter showed no significant differences. Similarly, Pizolato Neto et al. (2016) assessed $\mathrm{N}$ doses in irrigated corn cultivars and found no statistical differences between cultivars and applied $\mathrm{N}$ doses. Valderrama et al. (2011) and Biscaro et al. (2011) studied increasing topdressing $\mathrm{N}$ doses in corn and observed no increase in stem diameters of plants receiving $\mathrm{N}$.

The averages of shoot fresh matter fitted the quadratic regression model (Figure 2), with a coefficient of determination of $78.45 \%$ and a cutoff point of maximum efficiency at the dose of $271.90 \mathrm{mg} \mathrm{dm}^{-3}$, thus maintaining an intermediate dose between 200 to $300 \mathrm{mg} \mathrm{dm}^{-3}$.

Cessa et al. (2017) tested $\mathrm{N}$ and zinc doses applied via leaf and found that fresh matter may have increased due to their leaf contents. Oliveira and Caires (2003) observed an increase in the $\mathrm{N}$ contents of diagnosed corn leaves as the doses of $\mathrm{N}$ applied to the soil were raised.

Regarding leaf area index (Figure 3), the data fitted significantly $(p \leq 0.01)$ to a $2^{\text {nd }}$-degree regression equation, with a coefficient of determination of $80.41 \%$ and a cutoff point of maximum efficiency at $336.91 \mathrm{mg}$ $\mathrm{dm}^{-3}$. One of the hypotheses for this is the function of $\mathrm{N}$ in cell metabolism as an activator of several enzymes, increasing cell growth and expansion and resulting in higher leaf growth and cell structure.

According to Morais et al. (2015), increases in leaf area index can be justified by $\mathrm{N}$ essential role in plant metabolism, participating directly in the biosynthesis of proteins and chlorophylls, increasing photosynthetic rates and hence leaf area index. Fagundes et al. (2007) assessed the effect of $\mathrm{N}$ sources and doses on growth, development, and leaf senescence retardation of sunflower grown in pots and observed an increase in leaf area with an increase in $\mathrm{N}$ doses.

Mumbach et al. (2017) assessed Azospirillum brasilense inoculation associated with $\mathrm{N}$ fertilization in wheat and off-season corn plants and obtained no significant results for leaf area. On the contrary, Santos et al. (2017) evaluated canopy structure and tiller characteristics of Piatã grass pastures managed with different $\mathrm{N}$ doses and varying deferral periods; they observed significant differences in leaf area index as $\mathrm{N}$ was applied, regardless of deferral periods.

Shoot dry matter (Figure 4) showed significant differences ( $p \leq 0.01)$, with data fitted to a $2^{\text {nd }}$-degree regression equation, coefficient of determination $\left(\mathrm{R}^{2}\right)$ of 0.5768 , and cut off point of maximum efficiency at the dose of $279.66 \mathrm{mg} \mathrm{N} \mathrm{dm}^{-3}$ soil. Souza et al. (2013) tested $\mathrm{N}$ fertilization in wheat and found an increase in shoot dry matter as $\mathrm{N}$ dose increased, with a maximum dry matter production at a dose of $165 \mathrm{mg} \mathrm{N} \mathrm{dm}^{-3}$ soil.

Plants properly nourished with $\mathrm{N}$ have higher vegetative development, as such nutrient directly influences cell division and expansion, besides being essential for photosynthesis as a constituent of chlorophyll molecules (Büll, 1993). Fresh root matter was significant at $5 \%$ probability by the F-test, with an average of about $250 \mathrm{~g}$ fresh matter pot $^{-1}$ and a trend line similar to the other parameters, fitting to a quadratic regression model (Figure 5).

Root volume (Figure 6) also showed significant differences ( $p \leq 0.01$ ), with averages fitted to a $2^{\text {nd }}$ degree regression equation and cutoff point of maximum efficiency at the dose of $272.9 \mathrm{mg} \mathrm{dm}^{-3}$, following the same pattern of the other parameters. Such a value is close to the maximum agronomic efficiency found for plant height $\left(248.83 \mathrm{mg} \mathrm{dm}^{-3}\right)$, shoot fresh matter $\left(271.90 \mathrm{mg} \mathrm{dm}^{-3}\right)$, shoot dry matter $\left(279.66 \mathrm{mg} \mathrm{dm}^{-3}\right)$, and root volume $\left(272.9 \mathrm{mg} \mathrm{dm}^{-3}\right)$.

Silva et al. (2018) found that as $\mathrm{N}$ dose is raised, root volume increases since it favors root spreading towards a larger soil area, thus reducing $\mathrm{N}$ losses. Contrasting results were found by Morais et al. (2015), who observed that $\mathrm{N}$ absence contributes to a higher root system. In this sense, Bonifas et al. (2005) mentioned that roots tend to develop more to explore a larger soil volume to supply the deficiency in N-limited environments.

In short, increasing $\mathrm{N}$ doses provided a higher initial development of corn plants as $\mathrm{N}$ is part of organic compounds such as amino acids, protein, chlorophyll, and many essential enzymes, which stimulate corn shoot and root growth and development. Moreover, $\mathrm{N}$ is indispensable in several vital processes such as protein synthesis, ionic absorption, photosynthesis, plant respiration, as well as cell multiplication and differentiation (Marschner, 1995). 
Table 1. Summary of analysis of variance (F-test) for corn plant height (PH), stem diameter (SD), shoot fresh matter (SFM), root fresh matter (RFM), shoot dry matter (SDM), root dry matter (RDM), leaf area index (LAI), and root volume (RV) as a function of nitrogen doses.

\begin{tabular}{lcccccccc}
\hline Variation Source & PH & SD & SFM & RFM & SDM & RDM & LAI & RV \\
\hline Treatment & $18.53^{* *}$ & $1.3^{\mathrm{ns}}$ & $13.97^{* *}$ & $3.14^{* *}$ & $5.72^{* *}$ & $1.8^{\mathrm{ns}}$ & $17.10^{* *}$ & $4.65^{*}$ \\
\hline CV & 4.69 & 12.90 & 11.93 & 23.21 & 21.11 & 48.67 & 18.73 & 21.91 \\
\hline
\end{tabular}

${ }^{*}$ Significant at $5 \%$ probability, ${ }^{* *}$ significant at $1 \%$ probability, and ${ }^{\mathrm{ns}}$ non-significant. CV: coefficient of variation.

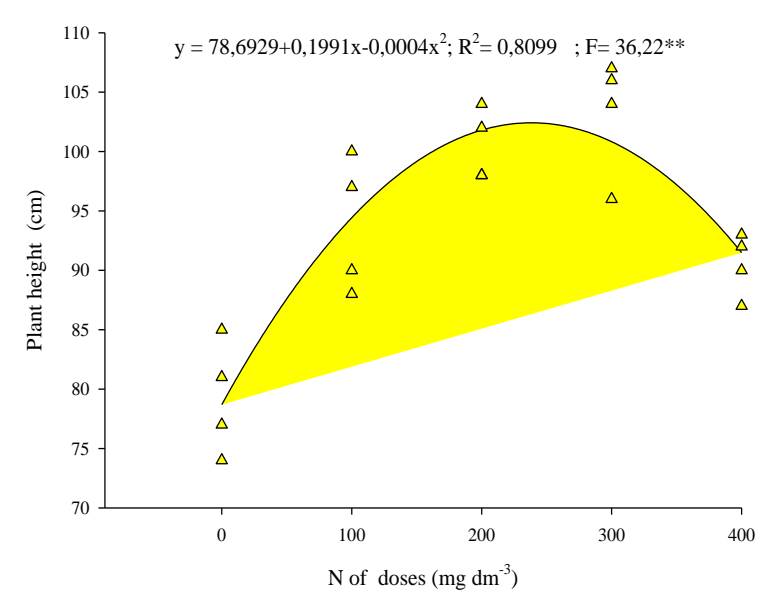

Figure 1. Regression of the effect of nitrogen doses on plant height $(\mathrm{cm})$ of corn.

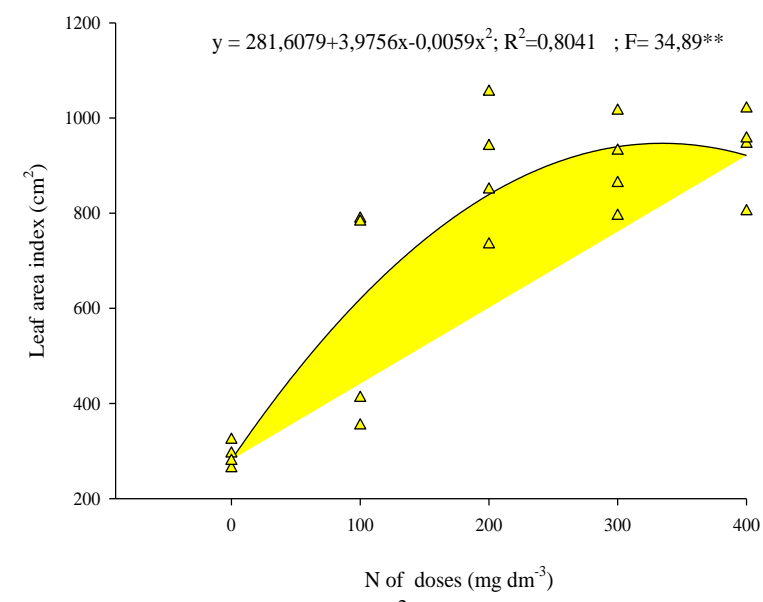

Figure 3. Leaf area index $\left(\mathrm{cm}^{2}\right)$ as a function of the application of nitrogen doses in corn.

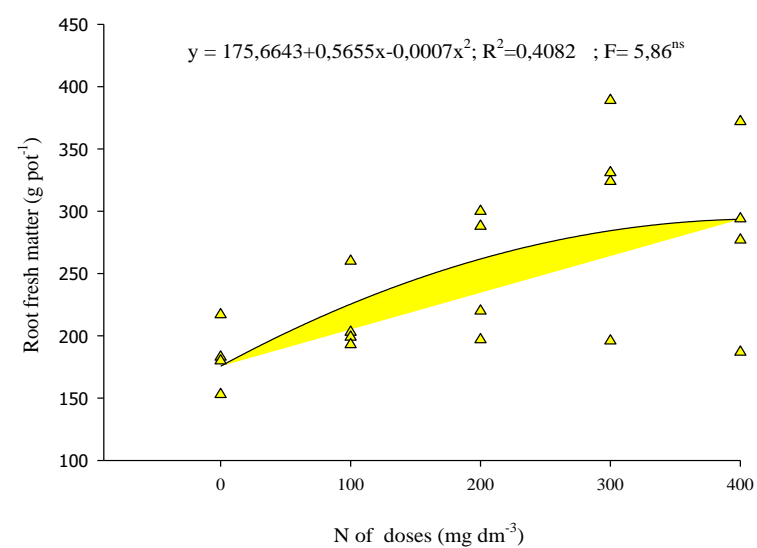

Figure 5. Root fresh matter $\left(\mathrm{g} \mathrm{pot}^{-1}\right)$ as a function of the application of nitrogen doses in corn.

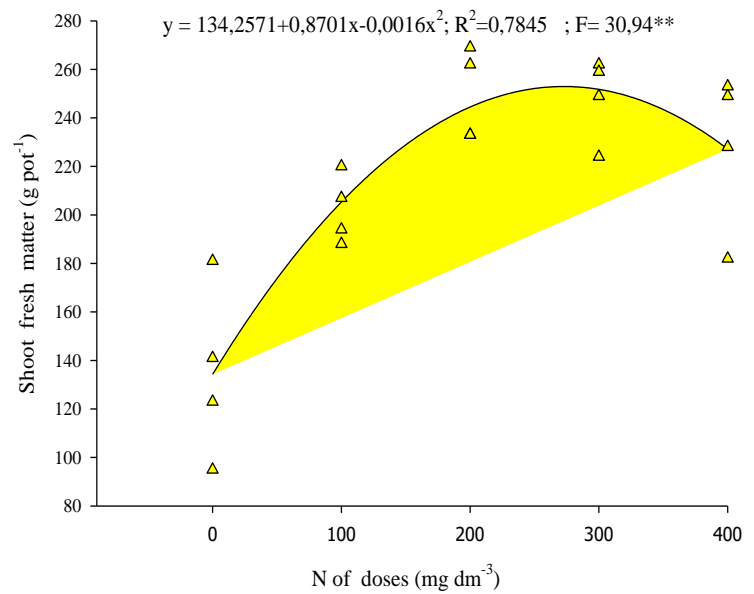

Figure 2. Shoot fresh matter $\left(\mathrm{g} \mathrm{pot}^{1}\right)$ as a function of the application of nitrogen doses.

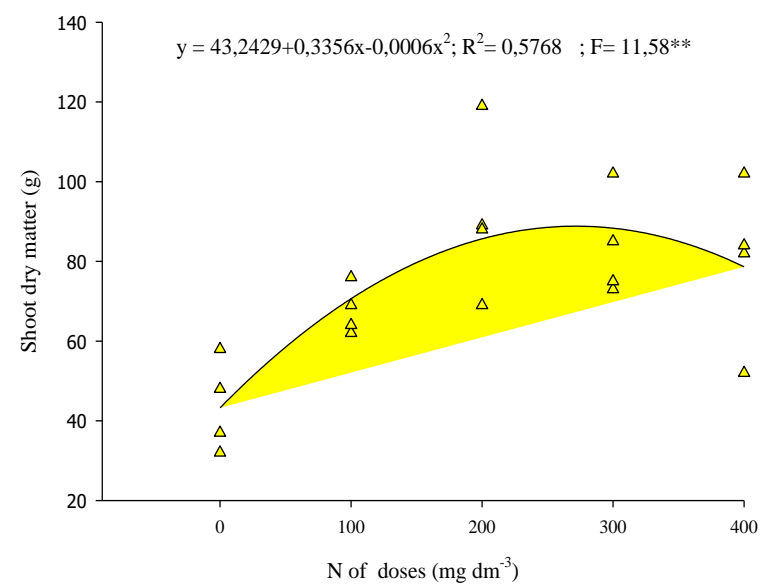

Figure 4. Shoot dry matter $(\mathrm{g})$ as a function of the application of nitrogen doses in corn.

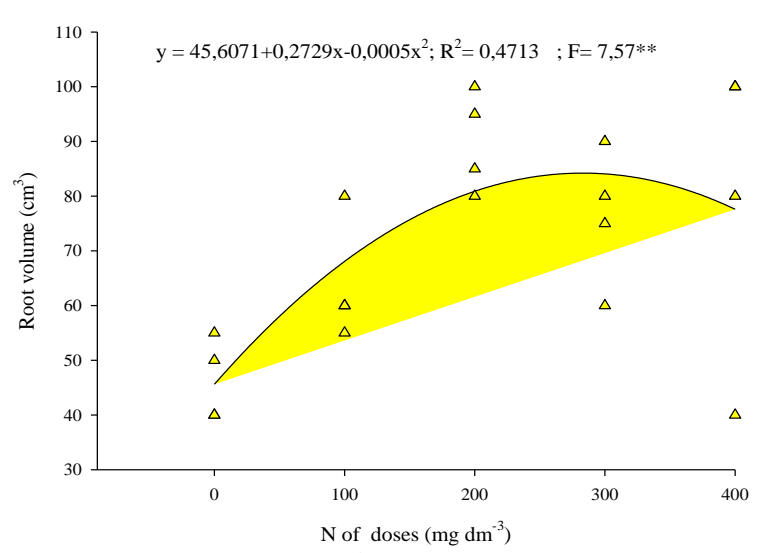

Figure 6. Root volume $\left(\mathrm{cm}^{3}\right)$ as a function of the application of nitrogen doses in corn. 


\section{Conclusions}

Nitrogen doses influence the initial development of corn plants, except for stem diameter and root dry matter.

Increasing $\mathrm{N}$ doses up to $248.83 \mathrm{mg} \mathrm{dm}-3$ implies an increase in vegetative development without causing deleterious effects to corn crops at the initial stages.

\section{Authors' Contribution}

Dhiego César Oliveira Riva Neto, Leonardo Rodrigues Barros, Vinicius Silva Souza made the evaluation, interpretation of data and preparation of the manuscript; Eliana Paula Fernandes Brasil, Adriana Aparecida Ribon and Alex Oliveira Smaniotto collaborated in the analysis and interpretation of data, review of statistical analysis and supervision critical of the manuscript regarding intellectual content.

\section{Bibliographic References}

Alva, A.K., Paramasivam, S., Fares, A., Delgado, J.A., Mattos Junior, D., Sajwan, K. 2005. Nitrogen and irrigation management practices to improve nitrogen uptake efficiency and minimize leaching losses. Journal of Crop Improvement, 15(2), 369-420. DOI: https://doi.org/10.1300/J411v15n02_11

Alves, B.M., Cargnelutti Filho, A., Toebe, C.B.M., Silva, L.P. 2015. Divergências genéticas de milho transgênico em relação à produtividade de grãos e da qualidade nutricional. Ciência Rural, 45(5), 884-891. DOI: https://doi.org/10.1590/0103$8478 \mathrm{cr} 20140471$

Andrade, F.R., Petter, F.A., Nóbrega, J.C.A., Pacheco, L.P., Zuffo, A.M. 2014. Desempenho agronômico do milho a doses e épocas de aplicação de nitrogênio no Cerrado piauiense. Revista de Ciências Agrárias, 57(4), 358-366. DOI: http://dx.doi.org/10.4322/rca.1295

Biscaro, G.A., Motomiya, A.V.A., Ranzi, R., Vaz, M.A.B., Prado, E.A.F., Silveira, B.L.R. 2011. Desempenho do milho safrinha irrigado submetido a diferentes doses de nitrogênio via solo e foliar. Revista Agrarian, 4(11), 10-19.

Bonifas, K.D., Walters, D.T., Cassman, K.G., Lindquist, J.L. 2005. The effects of nitrogen supply on root: shoot ratio in corn and velvetleaf. Weed Science, 53(5), 670-675. DOI: https://dx.doi.org/www.jstor.org/stable/4047036

Büll, L.T. Nutrição mineral do milho. 1993. In: Büll, L.T., Cantarella, H. (Ed.). Cultura do milho: fatores que afetam a produtividade. Piracicaba, Potafos, p. 63-145.

Caioni, S., Lazarini, E., Parente, L.T., Pivetta, S.R., Souza, M.G.L. 2016. Nitrogênio e Molibdênio para milho irrigado em região de cerrado de baixa altitude, Revista Brasileira de Milho e Sorgo, 15(3), 418-427. DOI: https://doi.org/10.18512/1980-6477/rbms.v15n4p418-427

Cessa, A.M.R., Lima, F.S.L., Melo, P.E. 2017. Pulverização foliar com nitrogênio e zinco em milho (Zea mayz L.) "Safrinha em Confresa-MT, Revista Agrogeoambiental, 9(1),
55-64. DOI:

$1817 \mathrm{v} 9 \mathrm{n} 12017869$

CONAB. COMPANHIA NACIONAL DE ABASTECIMENTO. 2020. Ministério da Agricultura, Pecuária e Abastecimento. Acompanhamento da Safra Brasileira de Grãos, safra 2019/20. Brasília, Ministério da Agricultura, Pecuária e Abastecimento, 20 p.

EMBRAPA. EMPRESA BRASILEIRA DE PESQUISA AGROPECUÁRIA. 2018. Centro Nacional de Pesquisa de Solos. Sistema brasileiro de classificação de solos. Brasília, Empresa Brasileira de Pesquisa Agropecuária, 356 p.

Fagundes, D.J., Santiago, G., Mello, M.A., Bellé, A.R., Streck, A.N. 2007. Crescimento, desenvolvimento e retardamento da senescência foliar em girassol de vaso (Helianthus annuus L.): fontes e doses de nitrogênio. Ciência Rural, 37(4), 987-993. DOI: http://dx.doi.org/10.1590/s010384782007000400011

Fancelli, A., E Dourado Neto, D. 2000. Produção de milho. Guaíba: Agropecuária, 360p

Farinelli, R., Lemos, L.B. 2012. Nitrogênio em cobertura na cultura do milho em preparo convencional e plantio direto consolidados. Pesquisa Agropecuária Tropical, 42(1), 63-70. DOI: https://doi.org/10.1590/S1983-40632012000100009

Francis, C.A., Rutger, J.N., Palmer, A.F.E. 1969. A rapid method for plant leaf area estimation in maize (Zea mays L.). Crop Science, 9(5), 537-539. DOI: https://doi.org/10.2135/cropsci1969.0011183X000900050005 $\mathrm{x}$

Galvão, J.C.C., Miranda, G.V. 2011. Produção de milho em pequenas propriedades. CPT, Viçosa.

Marschner, H. 1995. Mineral nutrition of higher plants. London: Academic Press. 889p.

Morais, M., Amaral, H.F., Nunes, M.P. 2018. Desenvolvimento e assimilação de nutrientes da cultura de milho inoculado com Azospirillum brasilense e diferentes doses de nitrogênio e potássio. Revista Terra \& Cultura, 34(especial), 160-176. DOI: http://doi.org/periodicos.unifil.br/index.php/Revistateste/articl $\mathrm{e} / \mathrm{view} / 522$

Morais, T.P., Brito, C.H., Ferreira, A.S., Luz, J.M.Q. 2015. Aspectos morfofisiológicos de plantas de milho e bioquímico do solo em resposta à adubação nitrogenada e à inoculação com Azospirillum brasilense. Revista Ceres, 62(6), 589-596. DOI: https://doi.org/10.1590/0034-737X201562060012

Mumbach, L.G., Kotowski, E.I., Scheneider, A.J.F., Mallman, S.M., Bonfada, B.E., Portela, O.V., Bonfada, B.E., Kaiser, R.E. 2017. Respostas da inoculação com Azospirillum brasilense nas culturas de trigo e de milho safrinha. Scientia $\begin{array}{llll}\text { Agraria, } & \text { 18(2), } & 97-103 . & \text { DOI: }\end{array}$ http://dx.doi.org/10.5380/rsa.v18i2.514775

Oliveira, J.M.S., Caires, E.F. 2003. Adubação nitrogenada em cobertura para o milho cultivado após aveia preta no sistema plantio direto. Acta Scientiarum. Agronomy, 25(2), 351-357. DOI: https://doi.org/10.4025/actasciagron.v25i2.1926 
Pizolato Neto, A., Camargos, A.E.V., Valeriano, T. B., Sgobi M. A., Santana, M. J. 2016. Doses de Nitrogênio para cultivares de milho irrigado. Nucleus, Revista Cientifica da Fundação Educacional de Ituverava, 13(1), 87-96. DOI: https://doi.org/10.3738/1982.2278.1606

Rolim, R.R., Pinto, A.A., Camara, F.T., Mota, A.M.D., Silva, C.S. 2018. Produtividade e rentabilidade do milho em função do manejo da adubação na região do Cariri-CE. Revista Científica Rural, 20(1), 204-221.

Santos, R.M.E., Sousa, L.M.B., Rocha, O.G., Freitas, S.A.C., Silveira, T.C.M., Sousa, C.O.D. 2017. Estrutura do dossel e características de perfilhos em pastos de capim-piatã manejados com doses de nitrogênio e períodos de diferimento variáveis. Ciência Animal Brasileira, 18, 1-17. DOI: https://doi.org/10.1590/1089-6891v18e-37547

Santos, W.F., Afférri, F.S., Pelúzio, J.M., Sodré, L.F., Rotili, E.A., Cerqueira, F.B., Ferreira, T.P.S. 2018. Genetic diversity in maize under nitrogen restriction conditions. Journal of Bioenergy and Food Science, 5(2), 44-53. DOI: http://dx.doi.org/10.18067/jbfs.v5i2.190

Silva, H.S., Carvalho, M.A.B., Souza, A.P., Barbosa, E.S., Pereira Neto, J.M., Vieira, C.P. 2018. Distribuição especial de raízes de milho submetido a adubação mineral em sistemas de plantio direto. In.: Zuffo, A.M., Aguilera, J.G. Solos nos biomas brasileiros. 2 ed. Atena, 2(3), 17-27.
Souza, P. S., Silva, B. M. E., Schlichthing, F.A., Silva, C.M. 2013. Desenvolvimento inicial de trigo sob doses de nitrogênio em latossolo vermelho de cerrado. Revista Brasileira Agrícola e Ambiental, 17(6), 575-580. DOI: http://dx.doi.org/10.1590/S1415-43662013000600001

Teixeira Filho, M.C.M., Buzetti, S., Andreotti, M., Arf, O., Benett. C.G.S., 2010. Doses, fontes e épocas de aplicação de nitrogênio em trigo irrigado em plantio direto. Pesquisa Agropecuária Brasileira, 45(8), 797-804. DOI: http://dx.doi.org/10.1590/S0100-204X2010000800004.

Valderrama, M., Buzetti, S., Benett S.G.C., Andreotti, M., Teixeira Filho, M.C.M. 2011. Fontes e doses de NPK em milho irrigado sob plantio direto. Pesquisa Agropecuária $\begin{array}{lll}\text { Tropical, } & 41(2), & 254-263 .\end{array}$ https://doi.org/10.5216/pat.v41i2.8390

Veloso, M.E.C., Duarte, S.N., Dourado Neto, D., Miranda, J.H., Silva, E.C., Sousa, V.F. 2006. Doses de nitrogênio na cultura do milho, em solos de várzea, sob sistema de drenagem subterrânea. Revista Brasileira de Milho e Sorgo, 5(3), 382- 394. DOI: https://doi.org/10.18512/19806477/rbms.v5n03p\%25p

Vieira, C.V., Moro, V., Farinacio, D., Martin, N.T., Menezes, G.F.L. 2011. Caracterização da silage de milho, produzida em propriedades do sudoeste do Paraná, Revista Ceres, 58(4), 462-469. DOI: https://doi.org/10.1590/S0034737X2011000400009 